\title{
Hinterland Transportation in Europe: Combined Transport versus Road Transport
}

\author{
Antoine Frémont \\ Director of Research \\ INRETS (French National Institute for Transport and Safety Research)-SPLOTT (Production \\ Systems, Logistics, Transport Organization and Work). \\ Le Descartes 2, 2, rue de la butte verte, 93166 Noisy Le Grand Cedex. \\ antoine.fremont@inrets.fr \\ http://www.inrets.fr/ur/splot/
}

\section{Pierre Franc}

Engineer and Ph.D Candidate

${ }^{1}$ INRETS (French National Institute for Transport and Safety Research)-SPLOTT (Production Systems, Logistics, Transport Organization and Work). Le Descartes 2, 2, rue de la butte verte, 93166 Noisy Le Grand Cedex. Telephone + 331459256 79, pierre.franc@inrets.fr

http://www.inrets.fr/ur/splot/

\section{Introduction}

Containerization is one of the main backbones of globalization. In fifty years, it has totally transformed international freight distribution chains. A virtuous circle has been set up in which the use of ever-larger vessels, with its consequent large economies of scale and reduction in the cost per transported TEU, goes hand in hand with an increase in transported volumes (Cullinane et al., 2000; Brooks, 2000).

Port hinterland services mostly rely on road transport in Europe. However, the enduring growth in port traffic is challenging the dominance of road for hinterland services because of costs, congestion and growing environmental constraints. For hinterland transportation high volumes are achieved by using rail-road or waterway-road transport. The ability of transport operators to attract freight from the hinterland at the lowest possible cost and with reliable and regular services is an essential condition for them to gain or maintain an advantage in a competitive environment. Consequently, ports that manage to be called by the largest container vessels and that are offering high volume inland services will reach the status of the major loading centre of their maritime range; they are able to control a large 
hinterland (Hayuth, 1992; Heaver, 2002; Robinson, 2002; Panayides et al, 2002; Notteboom, 2004). The major ports could also be the result of a very strong local hinterland.

However, combined transport must still demonstrate that it can compete with road transport. The combined transport is an intermodal transport where the major part of the European journey is by rail, inland waterways or sea and any initial and/or final legs carried out by road or as short as possible ${ }^{1}$ (ECE, 2001). Certain conditions must be met for combined transport to be set up, such as the setting of waterway or rail infrastructure, sufficient volumes of geographically concentrated flows and the presence of transport integrators providing door-todoor services to shippers. In addition to these conditions, the intermodal option might be successful because of reliability and the possibility to massify flows. However, it can be argued that the price remains, quite often, the critical factor. These conditions will looked over for the ports in the Northern European range, with a particular focus on river services from the port of Le Havre to the Paris region. This case study, for which pricing data has been collected, is of particular interest as the position of Le Havre is much less favorable for the development of combined transport than for the other main ports along the Hamburg-Le Havre range. In fact, the port of Le Havre does not trigger high volumes as Antwerp, Rotterdam or Hamburg. It is quite far from most of European dynamics regions. Only the Paris region leads important flows of containers. In this condition, barge-road and rail-road combined transport encounter difficulties to deliver frequent and cost effective services. In addition, the railroad combined transport often lack at meeting the reliability standards of the customer.

In the first part of this paper, it is shown that a large number of actors in the different ports of the Northern European range share a dynamic that is very favorable to the development of combined transport. However, conditions are very different from one port to the other, which means that the development of combined transport varies substantially. The organizational patterns of road and combined transport are then investigated. There are, in fact, two different transport services which are not immediately comparable. The example of inland shipping between the port of Le Havre and the Paris region will then be used to highlight the extent to which combined transport is competitive in terms of price and services compared with different organizational patterns of road transport.

\footnotetext{
${ }^{1}$ In comparison, intermodal transport is the movement of goods in one and the same loading unit or road vehicle, which uses successively two or more modes of transport without handling the goods themselves in changing modes.
} 


\section{A shared dynamic, different starting positions}

\subsection{Common issues}

A shared dynamic, which is the outcome of several factors, leads to the use of combined waterway-road or rail-road transport for hinterland services from maritime ports. Although the benefits they derive differ, the various port stakeholders are all concerned about three issues promoting the use of combined transport: cost, traffic flow and the environment.

Three types of port stakeholders can be found. The first are economic agents, which are directly involved in organizing transport operations, including shippers, shipping lines, forwarders and freight handlers. The second are public authorities, which mainly consist of port management and various regional levels of decision-making from the State to the municipalities and including the regions. The third concerns community groups, which is most often expressed through the media or lobbying groups, in particular environmental associations, which represent social demands.

\subsubsection{Costs}

Organizing a door-to-door combined transport chain requires freight handling at the maritime and inland terminals, rail or barge transport between those terminals and a pre- or post- haulage between the inland terminal and the shipper or logistics supplier. Combined transport partially extends inland the economies of scale that are achieved on the sea by very large vessels. Therefore, even if the organizational complexity of combined transport is greater than the one of road transport, the volumes handled by combined transport reduce costs on the inland transport leg. Double-stack unit trains in North America with a capacity of 400 TEUs are a salient example. In Europe, economies of scale are smaller as the largest block trains only have a capacity of 80 to 95 TEUs. On waterways the capacity of larger convoys partly depends on the quality of the infrastructure but it may take up to 500 TEUs on the Rhine. The costs of combined transport also depends on the length of rail or barge haul, pre- and post- road distance, balance of traffics, location of inland terminal (Niérat, 1997).

The costs of combined transport are only a part of broader logistics costs which include warehousing, stuffing/un-stuffing of containers, customs clearance and a forecast cost taking into account transit time and reliability. However, for FCL containers, shippers require services focused especially on door to door transport and thus, the inland transport, particularly combined transport, takes an important part of the door to door costs. 
Consequently, the issue of inland transport costs primarily involves the economic agents such as shippers since they have a direct impact on their operations. Shippers are therefore interested in the development of combined transport as it can result in lower supply chain costs. It is also obviously in the interest of the transport organizers, like shipping lines or freight forwarders to provide their clients with transport services that are cheaper than the road, particularly because of the competition that exists between them. For a shipping line, lower costs on the inland transport leg should provide higher volumes, resulting in consolidation and higher margins on the inland transport leg. Organizing efficient combined transport services help shipping lines to attract volumes and to fill the vessels rather than to increase profits on the inland leg (Franc, 2007). In addition, with the emergence of global trade imbalance (Rodrigue and Notteboom, 2009b), the repositioning of empty containers has become a key challenge for liners owning or leasing containers. In these conditions combined transport is more than just a full container transport service.

Promoting combined transport is also in the interests of the port management as a means not only of extending port hinterland but also to secure its customer base from possible competition from other ports along the same maritime range. Combined transport can extend a port's hinterland, enabling it to compete with another port's immediate hinterland. The neighboring port will therefore respond by also promoting combined transport in its hinterland in order to protect its catchment area. Public opinion is sensitive to these arguments as preserving or increasing port activity means jobs.

\subsubsection{Traffic flow}

Traffic flow refers not only to the congestion-free flow of containers within the port and the hinterland, but also added-value operations such as customs clearance that can be performed on the freight with minimal delay. Even if the port traffics tend to drop in 2009 due to the economic slowdown, most large ports have experienced a strong increase in container traffic during many years. Therefore, there is a risk for those ports to suffer from congestion problems, which threaten the reliability of the international transport chains within which they operate. There is danger risk for these ports that some of the traffic will be transferred to less congested secondary ports, as a result of what is known as the peripheral port challenge (Hayuth, 1981). By offering diversified transport supply and higher volumes than is possible by road, combined transport is one possible way of improving traffic volumes between the port and its hinterland (ECMT, 2006b). The issue of traffic flow is thus decisive not only for 
port managers but also for the public authorities as traffic flow is directly responsible for a share of a port's competitiveness (Notteboom and Winkelmans, 2001).

Using combined transport can therefore be in the interest of shippers if it is more reliable, particularly for meeting the requirements of just-in-time transport operations. Traffic flow is also an important issue for carriers as the reliability of the services they provide to their clients depends on it.

The increasing container transport volumes handled in main seaports have put the issues of sea terminal and hinterland transport capacities and performances on the agenda of terminal operators. They have to deal with the storage of containers at the deep-sea terminal and they also need barge and train services to evacuate huge containers and reduce dwelling times. This explains why some port terminal operators are involved in developing "extended gates” (Slack, 1999, Rodrigue and Notteboom, 2009).

\subsubsection{The environment}

Transport is the only major sector of the economy that is responsible for an ever growing percentage of total $\mathrm{CO}_{2}$ emissions (ECMT, 2006a). Most barges still use diesel engines which produce important emissions triggering a need to find solutions to improve barge transport performances (Wiegmans and Konings, 2007). Rail services often use diesel trains to run the last miles. But even if local truck emissions ( $\mathrm{NOx}, \mathrm{SO}_{2}$ ) have been reduced significantly over the last two decades by introducing cleaner engines, road transport is responsible, in most of the cases, for more $\mathrm{CO}_{2}$ emissions than combined transport. In average, waterways are more energy efficient per ton transported than rail (by a factor of 2 to 1) which itself is more energy efficient than road transport (by a factor of 2.6 to 1) (ADEME, 2006). In addition, a recent study has revealed that in the case of door-to-door transport between the port of Le Havre and the Paris region, combined waterway-road transport is responsible for between 20 and 50\% less carbon dioxide $\left(\mathrm{CO}_{2}\right)$ emissions than road transport (Franc and Frémont, 2009).

The environmental problem is primarily dealt with by the public authorities, particularly European Union which is at the forefront on this issue internationally. It receives strong support at national level from governments but also locally as there is very strong social pressure to reduce the environmental harm caused by economic activities, particularly transport. There is thus strong political and social pressure in favor of combined transport. 
These environmental concerns are increasingly taken on board by both shippers and carriers who at present see them as a way of expressing their commitment to sustainable development but which are unable to discount the possibility of ultimately including environmental costs in their transport costs. Those issues are summarized in Table 1.

Table 1. The benefits of combined transport for different stakeholders

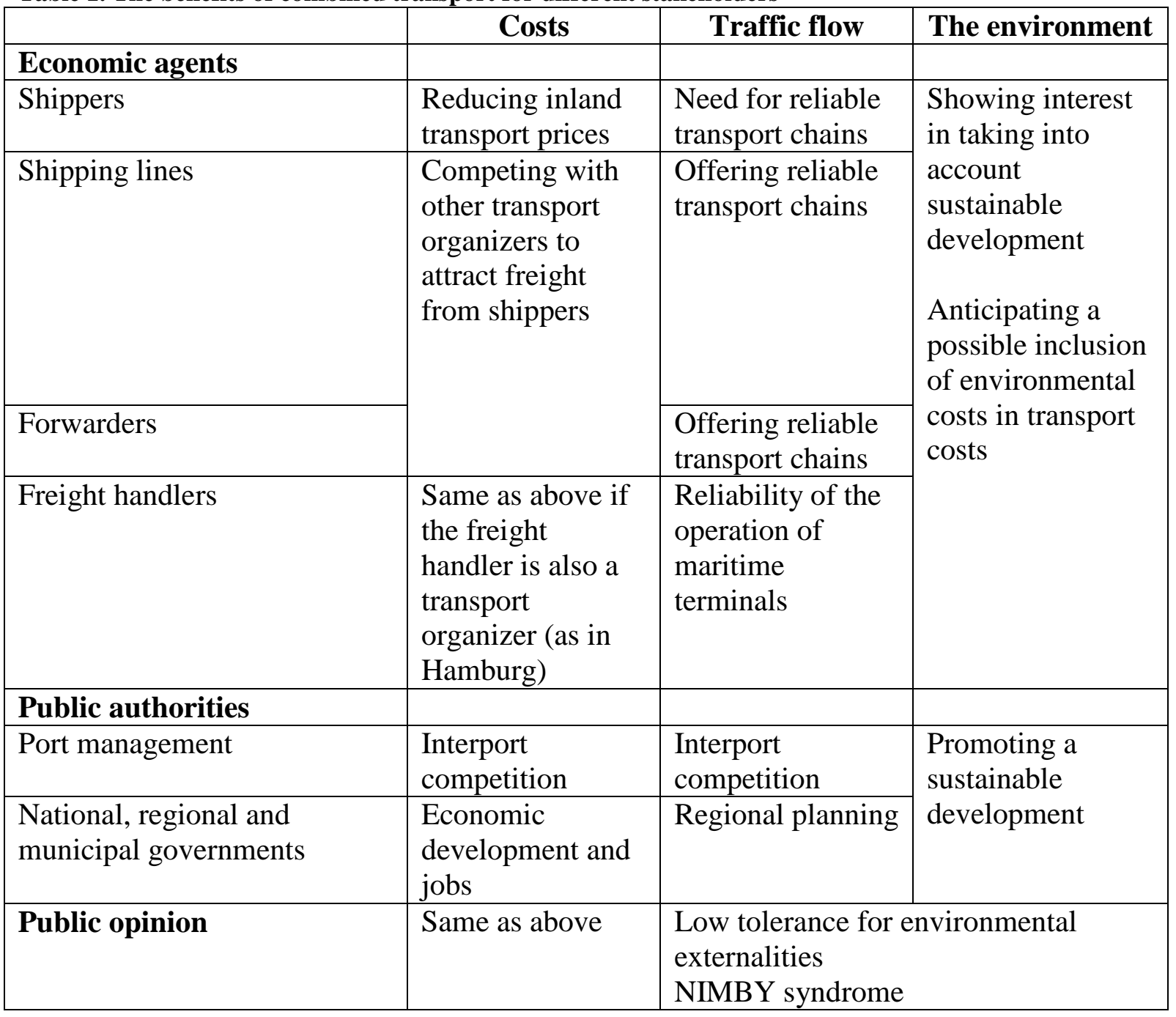

\subsection{The Northern Range ports: various conditions for combined transport}

All the Northern Range ports are currently involved in the development of combined transport. But the situation varies a great deal from one port to another as revealed by the modal split in the five largest ports in the range (Table 2). Le Havre is not only the port with the lowest traffic, it is the port where road dominates hinterland services. In the other four ports, road transport still accounts for more than $50 \%$ of hinterland services, but combined transport also plays a very important role, with waterway-road transport dominating in 
Antwerp and Rotterdam and railroad transport dominating for the two German ports of Hamburg and Bremerhaven.

Table 2. Hinterland traffic of Northern European Range ports in 2007

\begin{tabular}{|c|c|c|c|c|c|c|}
\hline & \multirow{2}{*}{$\begin{array}{c}\text { Traffic } \\
\text { (million } \\
\text { TEU) }\end{array}$} & \multirow[b]{2}{*}{$\begin{array}{l}\text { Transshipment } \\
\text { (\%) }\end{array}$} & \multirow{2}{*}{$\begin{array}{l}\text { Hinterland } \\
\text { traffic } \\
\text { (Million } \\
\text { TEU) }\end{array}$} & \multicolumn{3}{|c|}{ Modal split (\%) } \\
\hline & & & & Road & Rail & Barge \\
\hline Le Havre & 2,6 & 29 & 1,9 & 85,4 & 5,2 & 8,4 \\
\hline Antwerp & 8,2 & 16 & 6,9 & 58,8 & 9,4 & 30,6 \\
\hline Rotterdam & 10,8 & 24 & 8,2 & 58,6 & 10,9 & 30,5 \\
\hline Bremerhaven & 4,9 & 61 & 1,9 & 54,1 & 42,7 & 2,8 \\
\hline Hamburg & 9,9 & 37 & 7,2 & 67,3 & 30,2 & 2,7 \\
\hline
\end{tabular}

The development of combined transport in Antwerp, Rotterdam, Bremerhaven and Hamburg is explained by a virtuous circle, the result from a combination of several factors.

First, the Infrastructure. The Rhine with its tributaries is a natural waterway that penetrates more than 600 kilometers into Europe, providing access to the Rhineland of Germany, which is the economic core of the world's largest exporting economy. The principle of the free movement of freight vessels has applied on the Rhine since the Congress of Vienna in 1815.

Second, market characteristics. Traffic concentration along four ports is mainly explained by the wealth of their hinterlands, makes combined transport particularly attractive. It justifies the use of modes with extremely high capacities (Notteboom, 2004).

Third, the number of inland terminals and rail or waterway services has increased steadily over time, making combined transport more attractive to shippers (Notteboom et al, 2004). The nature of service patterns also affects the competitiveness of high volume modes (Konings, 2006).

Fourth, market organization is the most important factor. Actors are required to coordinate the transport chain (Van der Horst and De Langen, 2008). A handful of large transport organizers have structured combined transport services. In the two German ports, this has been done mainly by freight handlers which have set up rail services to new EU members, in particular Poland and the Czech Republic (Gouvernal et al, 2005; Debrie et al, 2006). On the Rhine, after a period of operation by small firms, a limited number of large waterway transport firms (Combined Container Service and Alcotrans Container Line in 1975, Rhinecontainer and Frankenbach in 1978) have emerged. From the early 1990s, inland waterways handled almost 30\% of Antwerp and Rotterdam's traffic. The 1990s saw the 
arrival of large firms performing both forwarding and logistics activities and which brought about vertical integration to the transport chain: Wincanton in 1990, Rhenus in 1995, Imperial Holding Logistics in 1998 (Zurbach, 2005). These three major forwarders control 70\% of containerized volumes on the Rhine ${ }^{2}$.

In Le Havre, change took place much more recently and primarily involved combined waterway-road transport. The combined transport market is driven by three shipping lines (Maersk, MSC and CMA-CGM) which own dedicated terminals (Frémont et al, 2009). The volumes controlled by these three shipping lines are sufficient to justify the provision of commercial combined transport services on the Seine between the port of Le Havre and the Paris region. Gennevilliers, in the immediate vicinity of Paris, is the principal inland terminal, which means that it is possible to run frequent and regular limited volume shuttle services. The three shipping lines are currently competing for the Paris region's freight via this new combined transport service. The involvement of the shipping lines has encouraged considerable growth in combined waterway-road transport from the port of Le Havre, with its market share increasing from less 3\% in 2001 to 8\% in 2006. Unlike the Rhine model where the forwarders dominate, the French model is organized by the shipping lines.

\section{The organization of road transport and combined transport}

The different factors and conditions have resulted in a variety of forms for combined transport development along the Northern European Range, which results in different situations where combined transport can be more attractive than the road. This is achieved through lower prices than road and by providing additional services.

However, before comparing road transport and combined transport with reference to prices and services, it is important to see how road transport and combined transport services are organized. In contrast to combined transport, road transport offers a choice of diversified organizational patterns. To begin with, road transport and combined transport do not offer the same physical transport service so the two are not directly comparable.

\subsection{The different types of hinterland services provided by road transport}

The road container transport community is constantly attempting to streamline transport, reducing costs and consequently prices. Starting with the provision of Round Trip services at the beginnings of containerization, trucking companies gradually developed other

\footnotetext{
${ }^{2}$ These figures date from 2004 given in the Annual Report of the Central Rhine Navigation Board
} 
services, all aiming at reducing distance travelled by each transported container. This includes the following organizational patterns

First, Round Trip (RT). For import flows, the container is unloaded from the vessel and taken full to the consignee, unstuffed then returned empty to a depot in the port where it was unloaded. Conversely, for export flows, the empty container is taken from a depot in the loading port. Half the inland journey is therefore performed with an empty container.

Second, One Way (OW). This differs from RT transport in that an inland depot (in the hinterland) serves as a hub from where the empty container is taken and to which it is returned. The distances covered by empty containers are therefore smaller than in RT transport as the distance between the client and the depot is shorter than the distance between the client and the port (otherwise OW transport would be not be justified).

Third, Cargo rotation. After the container is taken full to the client during the import journey, it is taken empty to an export client, refilled and returned full to the port or the inland port.

Fourth, RT double 20'. This is only possible for 20 foot containers which are light enough for the weight of the two 20 foot containers not to exceed the maximum permissible laden weight. Figure 1 shows only the situation where two containers are loaded or unloaded at the same client's premises. However, the two containers are often taken to and from different clients. Those organizations are summarized in Figure 1.

Figure 1. Different organizational strategies for road container transport

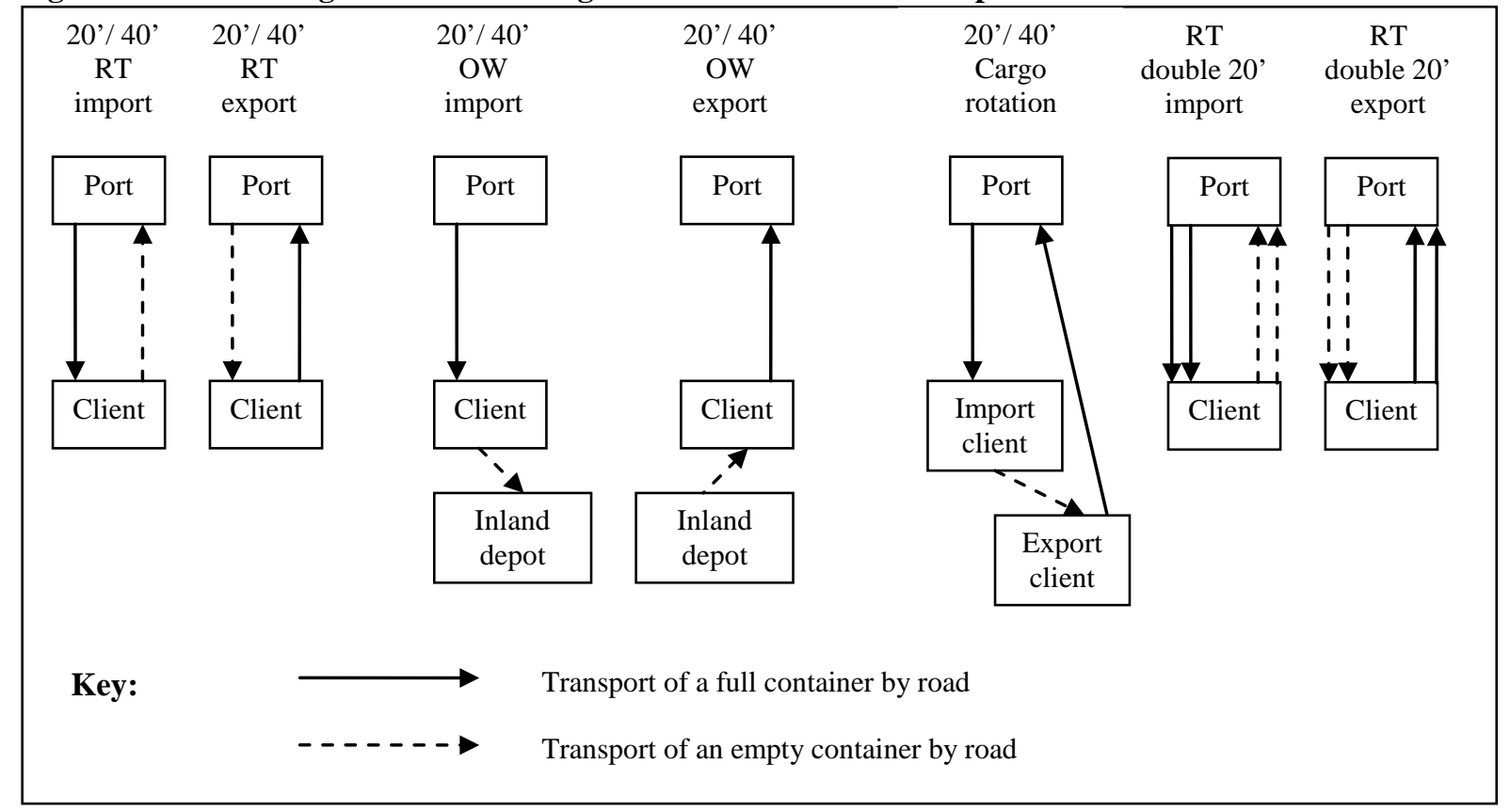

Source: authors 
Trucking companies charge different rates according to the different organizations of road container transport. The freight rate per unit of distance by RT is approximately $75 \%$ of the one charged by OW. So, in the case where the empty container depot is just next to a client, for import flows, RT transport would cost 1.5 times more than OW transport. The difference is explained by the willingness of trucking companies for RT transport since they will be paid for the return journey, whereas OW transport requires them to find a load for the return journey. In the case of OW, this uncertainty results in higher per-kilometre freight rates compared to RT transport. The rate per unit of distance by cargo rotation is calculated following the same rate per-kilometre as in OW. However, by bypassing the call of an inland depot, the cost of a cargo rotation is always smaller than the cost of two OW transports. Finally, for RT double 20', the price per container charged to freight forwarders or shipping lines is substantially smaller than the one by RT with only one container.

\subsection{Combined transport hinterland services}

Most combined transport involves the OW strategy (Figure 2). Moreover, the inland terminals where the shipping lines have not provided an empty container depot find it difficult to attract traffic. For import flows, the container is grouped with others in order to be transported by a high volume mode (train, barge) from the unloading port to the combined transport terminal. Before it is returned empty to the same combined transport terminal the full container is taken to the consignee and unstuffed there without being taken off the truck chassis. For export flows, the same procedures are carried out in reverse order.

Cargo rotation and the use of double container trucks are not as advantageous in the case of road transport of this type to or from an inland terminal as they are in the case of long haul road transport between a sea port and a client. The benefits of streamlining are smaller in the case of short distances than long distances. The detour that is necessary for cargo rotation may be negligible in the case of a long distance, but for a short distance it may be preferable to pass through the inland depot again. The same applies when a double container truck is used to serve two different clients. Consequently, most road transport to and from ports involves return journeys with one container at a time. 
Figure 2. Different organizational patterns for combined container transport

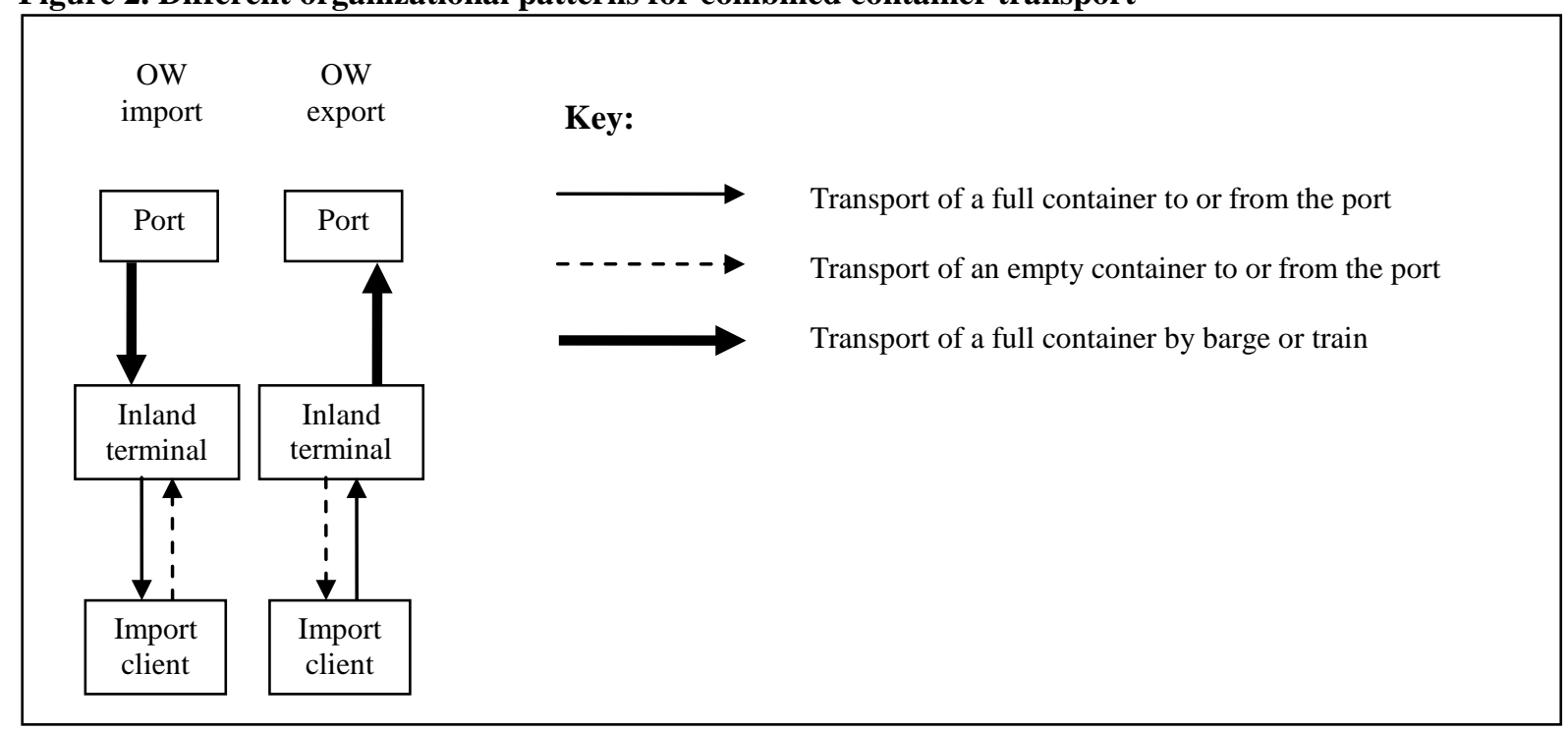

Source: authors

\section{Combined waterway-road versus road transport : exemple of the Le Havre/Paris leg.}

The competitiveness of transport by inland waterways is not pre-ordained. It only comes about as a result of a strategy to improve on the service provided by the road transport alternative. Waterway-road services must outperform road transport in terms of price, and reliability and logistics services. An analysis of waterway services to and from the port of Le Havre underlines some of the components of the competitiveness of water-borne transport.

\subsection{Prices}

Combined transport can be established instead of road transport if it provides lower prices. In the context of well-established road transport, transfer from road to combined transport will only occur if its pricing is attractive. According to a group transport operators that has been interviewed, the prices must be about 10 to $20 \%$ lower than the prices of road transport to be an incentive for a modal shift.

\subsubsection{Methodology}

In order to make price comparisons between the two modes, 2007 pricing schedules of a number of combined waterway transport operators at Le Havre and those of a number of trucking companies were examined. The pricing schedules of the road haulage operators reflected the different organizational patterns described above.

In Europe, and in France in particular, combined waterway-road transport uses the One Way (OW) organization. This means there must be inland depots to and from which the 
empty containers transported by combined transport are taken. However, these depots also help to perpetuate OW road transport as they are also used by road transport for returning empty containers, which improves its price competitiveness in comparison with a conventional RT service.

The prices of inland transport from the port of Le Havre were calculated on the basis of a breakdown of the Paris basin into "dico-route" zones ${ }^{3}$ (Figure 3). All the stakeholders involved in inland transport use long-established charts that calculate average distances. For instance, trucking companies calculate the price of a road transport by multiplying the average distance between two dico-route zones by the freight rate per unit of distance. This calculation is made either for a RT, OW, cargo rotation or RT double 20' depending on the expectation of the transport organizer.

\footnotetext{
${ }^{3} \mathrm{~A}$ « dico-route » zone is an area of roughly $100 \mathrm{~km}^{2}$. Transport providers elaborate their transport prices by using the distances between two "dico-route" zone revealed by tables.
} 
Figure 3: Breakdown of the Paris basin into “dico-route” zones

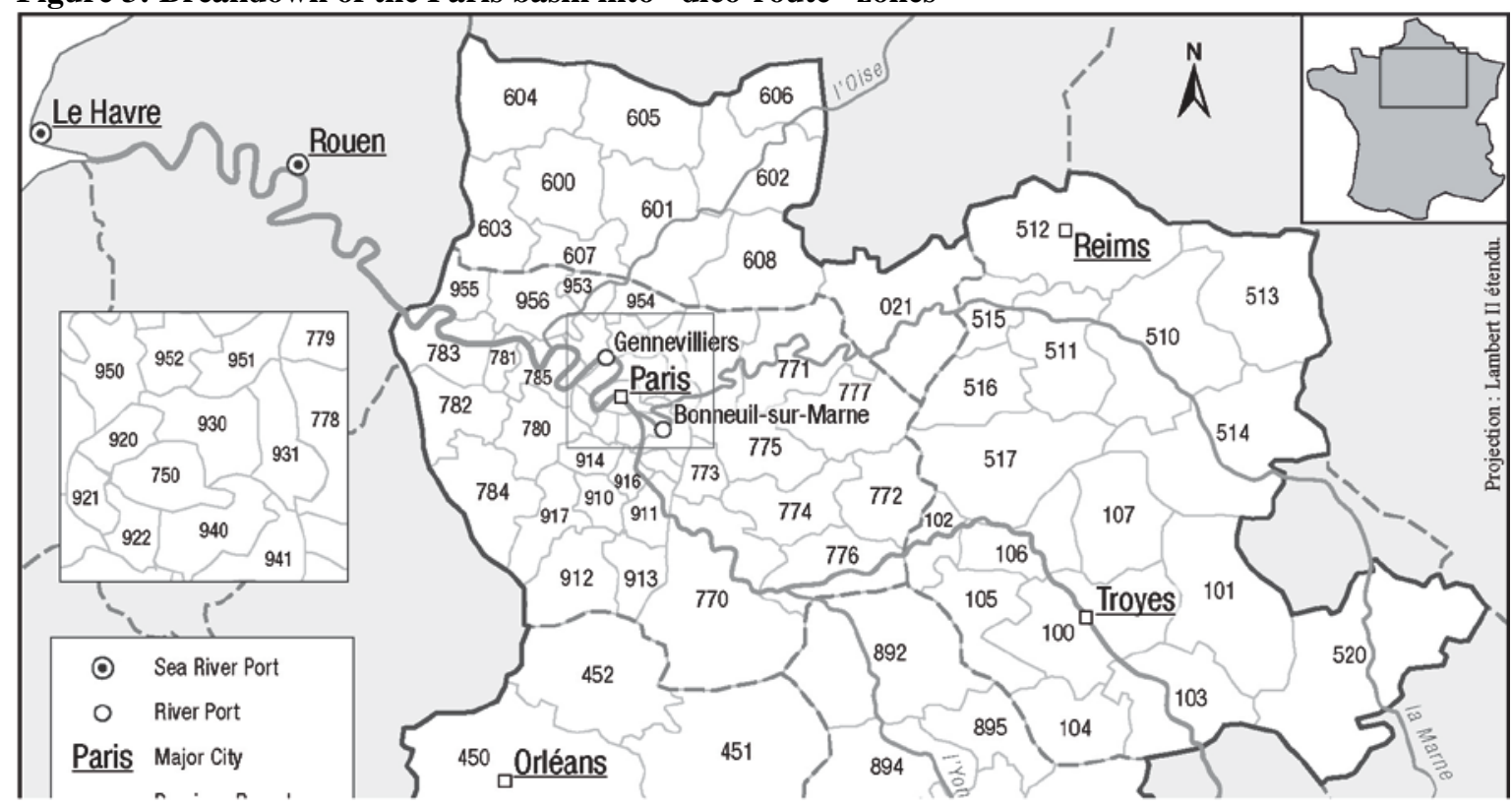

Freight forwarders and shipping lines are able to contract inland transport services in a number of ways. Import or export combined transport services for 20' or 40' containers are always sold to the forwarder or shipping line as an OW service. However, road transport services are marketed either as OW or RT services. The transport of 20’ containers weighing less than 13 tons can also be sold as an RT double container truck service. In view of the congestion problems in the Paris region, most road haulage operators in Le Havre charge a minimum price to carriers and/or freight forwarders which tends to drive up the price of road transport.

Then the price that is proposed to transport organizers - freight forwarders engaging in merchant haulage and shipping lines engaging in carrier haulage - by a combined transport operator to that proposed by a trucking company are compared. These prices do not include any commercial discounts. Neither the prices ultimately charged by the shippers were considered as they do not include the transport organizer's margin. Nevertheless, they clearly show the competitiveness of one mode in relation to the other. For instance, it is quite likely that if any discounts are applied to road transport for large volumes similar reductions will also be applied to combined transport. 
As the road constitutes the reference mode, the competitiveness of combined transport has been defined in the following way:

Percentage saving or loss resulting from the transfer to combined transport $=$ (price of combined transport - price of road transport)/ (price of road transport).

The further the result is below zero, the more competitive combined transport is in terms of price. Inversely, the further the result is above zero the more competitive road transport is.

Five maps have been drawn to show the influence of the type of container (20' or 40') and the organizational pattern of road transport (OW, RT or RT double 20') on the competitiveness of combined waterway-road transport (Figure 4). 
Figure 4: Prices of waterway-road combined transport versus road transport

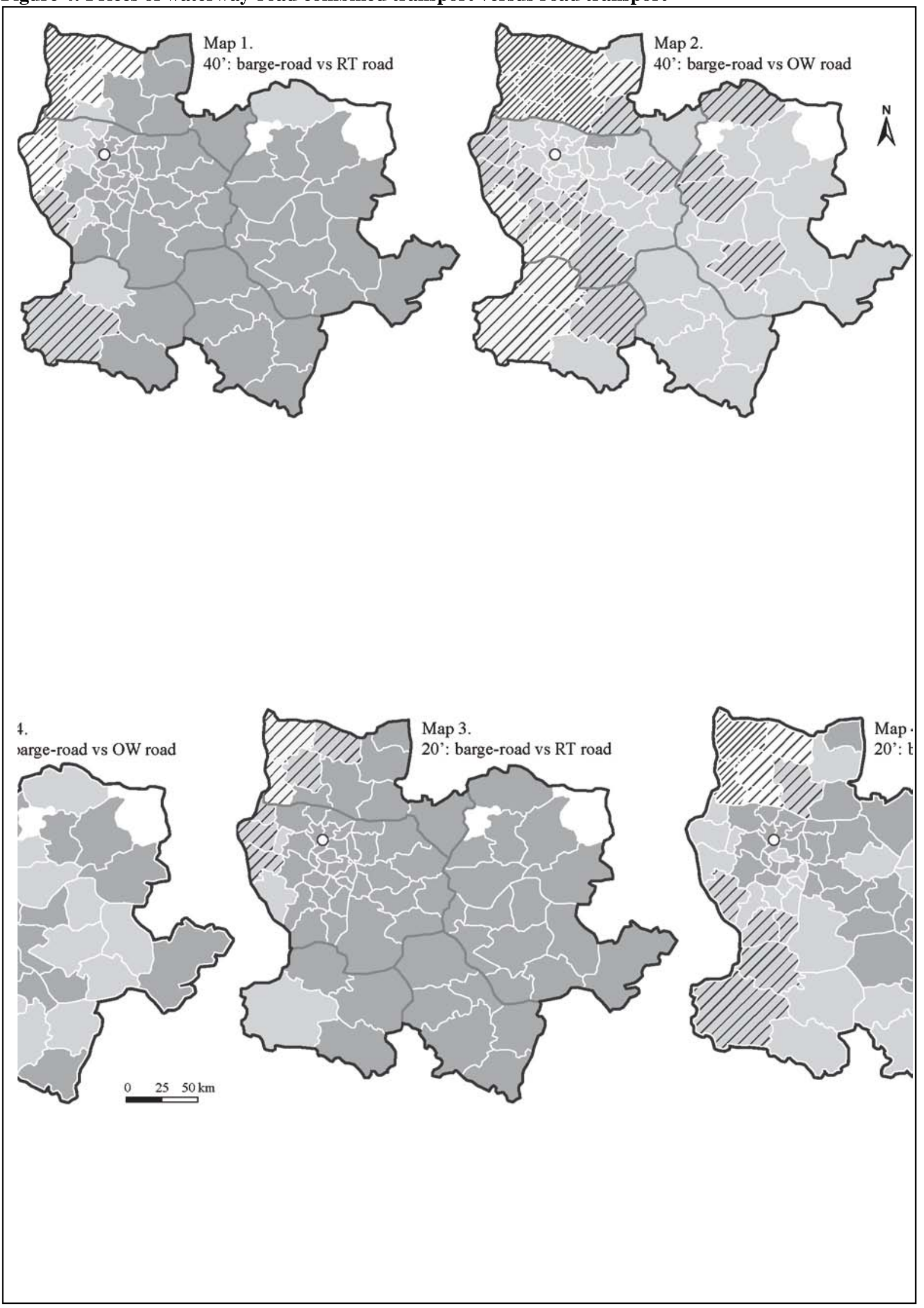




\subsubsection{Results}

It is apparent from the maps that, generally, combined transport is very competitive with road transport. Combined transport has a price advantage to the east of the Gennevilliers inland terminal, including for distant destinations more than $200 \mathrm{~km}$ from Gennevilliers (for example zone 520). However, to the west of the Gennevilliers terminal, towards the port of Le Havre, combined transport is not often competitive (for example zone 604) due to the fact that the road distance between the port of Le Havre and the client is almost as short than between the latter and the inland terminal of Gennevilliers.

The overall competitiveness of combined transport varies significantly according to the available road transport alternative. The combined mode is more competitive when the road transport alternative consists of RT rather than OW transport (comparing maps 1 and 2 ; maps 3 and 4). The reason for this is that RT road transport is more expensive than OW as the empty container has to be returned to the maritime terminal.

Combined transport is more competitive for the transport of 20' containers of more than 13 tons than for 40' containers (comparing maps 1 and 3). The reason for this is that a 20' container takes one barge slot while a 40' container takes two. For road transport, this additional load involves no price difference. However, the market area for combined transport shrinks considerably when the 20' containers weigh less than 13 tons and since road transport is able to use double container trucks (comparing maps 3 and 5).

The way road transport is organized has changed over time. It depends on the balance of power between the road haulage operators. The clients themselves have diverging interests. As far as the transport organizers are concerned, it is in the interest of the freight handlers to purchase the cheapest possible road transport, so they are not interested in purchasing RT transport. For the shipping lines, the problem of repositioning the empty container is added to the price of purchasing full container transport. This leads them to employ a variety of strategies depending on how well hinterland flows are balanced.

Different road haulage operators also have diverging preferences. For some, selling OW services is a way of ensuring they offer competitive services to their clients. Others consider that OW services may reduce their profit margins. Under such circumstances, the way the services are distributed between RT, OW and RT double 20' road services depends on the type of client and the strategic decisions made by trucking companies.

Combined transport's overall price competitiveness over such a large geographical area is also explained by the commercial willingness of the combined transport operators to promote the mode. The three largest shipping lines in the world are involved in the 
implementation of barge-road services. They are competing with each other for the very large hinterland that consists of the Paris region. This market is essential to justify their large vessels calling at their dedicated terminals at Le Havre, and recent additional investments at their terminals confirm this importance.

\subsection{The importance of additional services}

Price on its own is not enough to prompt actors in the transport chain to break their preferences leaning on road transport. In order to promote combined transport it is necessary to offer additional services that road transport does not provide. The development of combined waterway-road transport on the Seine reveals two stimuli which assist waterborne transport.

The first stimulus consists of offering more flexibility than the road as regards dwelling time. Lengthening the dwelling time for containers at inland terminals constitutes an initial incentive. Shipping lines often stipulate a demurrage time for containers. This is usually of the order of one or two weeks depending on the shipping lines and the trades ${ }^{4}$. Beyond this limit, most of the shipper pays a daily fee ${ }^{5}$. The free dwelling times that are fixed by the freight handlers in the port are added to the demurrage times. To give an example, storage is free for four to five days in the majority of the terminals at Le Havre. Beyond this limit, the shipper has to pay storage fees. Clients who use combined barge-road transport have extra free dwelling time at Le Havre, two days of waterway transport followed by eight more days of free dwelling time on the port of Gennevilliers. In addition, the storage fees at inland terminal are considerably lower than those at maritime terminals. Shippers therefore have more flexibility as regards the delivery day if they use combined barge-road transport. Some shippers make use of this opportunity to store their goods for a longer period.

This first stimulus combines with a second which offers customs facilities to shippers that use combined transport. For import flows, French customs and some combined transport operators have signed agreements that make it possible to set up simplified Community transit procedures. These grant combined transport operators the right to store import containers in Temporary Warehouse or Storage Areas in the Gennevilliers and Bonneuil-sur-Marne inland terminals for up to 45 days after their departure from Le Havre. This facility costs the shipper between $€ 20$ and $€ 30$ per container. The client can then have the container delivered to its

\footnotetext{
${ }^{4}$ Shipping line data

${ }^{5}$ Practice learns that large customers never pay such fees, although shipping lines are supposed to enforce such fees.
} 
warehouse. In the event of this being a bonded warehouse, the client has 20 more days before it becomes necessary to declare its freight. Consequently, the customs clearance deadline becomes 5 days in Le Havre +45 days in Paris (on condition storage fees at the inland terminal are paid) +20 days in a warehouse $=70$ days. This additional time is particularly attractive in view of the high customs clearance costs for a container. Major shippers, in particular large-scale distributors, are particularly interested by these arrangements. They mean they can wait until the products to be sold are on display in an outlet before making any payments. When end-consumers pay at the supermarket checkout, they pay almost at the same time as the distributor pays the customs charges. For export flows, there is a customs procedure that allows the formalities to be carried out during waterway transport which helps lower door-to-door transit times.

Thus, far from constituting a handicap for combined transport, the time factor becomes an asset of the first order. This confers flexibility for supply chain management by delaying the time when the decision is made to route the freight to a specific retailer or distribution center. It is establishing itself as an additional adjustment technique for freight just-in-time delivery times while at the same time offering greater flexibility for customs clearance.

\subsection{Incentives from the public authorities}

Public authorities are also taking measures to promote combined transport. The majority of European country governments subsidizes combined transport through different ways. For instance, the French Transport Ministry subsidizes cargo handling operations for containers that use combined transport what have been approved by the European Commission. In 2007, this aid amounted to $€ 12$ per container per handling operation. It can be increased on the basis of the number of handling operations carried out in France. The Transport Ministry can thus pay up to $€ 48$ per container, on condition the sum amounts to less than $30 \%$ of the hinterland transport costs.

The Autonomous Port of Paris (PAP) has also introduced commercial measures to encourage combined transport that involve reducing property costs by means of a "waterways package”. The principle is as follows: the more a shipper or forwarder located on land belonging to the PAP uses waterborne transport, the less rent it pays. This discount covers the transport costs for the "last mile”. Schenker and Les Grands Moulins de Paris, which are located at Gennevilliers on PAP land and which use combined waterway-road transport, take advantage of this arrangement. 


\section{Conclusion}

Combined transport is the only way forward to guarantee further growth of maritime traffic flows in North European seaports, with respect to both absolute value and relative value compared with road transport. To insure its further development, the price of combined transport must be lower than that of road transport. In order to compare the price of combined transport and road transport it is first of all necessary to highlight the different organizational patterns that are employed.

The example of hinterland services to and from the port of Le Havre shows that the competitiveness of combined transport in terms of price varies greatly according to the way road transport it competes with is organized. These variations in price underline that road and combined transport are services of two different types competing to carry freight between the same origins and destinations. Indeed, shippers also choose combined transport because of additional services which are not provided by road transport such as additional dwelling times and specific custom advantages. Paradoxically, the time factor is central to these additional services.

The competitiveness of combined transport compared with road transport is also due to the commercial policy of combined transport operators. The involvement of the three main shipping lines, Maersk, MSC and CMA CGM in the implementation of waterway-road services on the Seine tends to improve the competitiveness of this mode of transport. In order for clients to shift from road to combined transport prices must be between 10 and 20\% cheaper.

Le Havre is a particularly interesting case since combined transport operators manage to offer prices that are much lower, even though the high volume flows involve only a very short distance (the distance between Le Havre and Gennevilliers is around 200 kms by truck) which is a highly adverse situation for combined transport. On the Rhine, which is straight and much longer than the Seine, it should be possible to provide greater price differences, particularly in view that the transported volumes are much higher. The same applies to rail services from Hamburg and Bremerhaven.

In a matter of fact, this paper shows that deep analysis of the competitiveness of combined transport from ports cannot be implemented without having a high regard for the way the road transport is organized. These lessons open a new research agenda. 


\section{References}

ADEME (Agence de l'Environnement et de la Maîtrise de l'Energie). (2006), Transports combinés rail-route, fleuve-route et mer-route. Tableau de bord national 2006. Sophia Antipolis.

BROOKS, M.R. (2000), Sea Change in liner shipping, Oxford, Pergamon, 283p.

CULLINANE, K., KHANNA, M. (2000), "Economies of scale in large containerships: optimal size and geographical implications”, Journal of Transport Geography, 8, 181-195.

DEBRIE, J., GOUVERNAL, E. (2006), Intermodal Rail in Western Europe: Actors and Services in a New Regulatory Environment, Growth and Change, Vol.37, No. 3, pp 444-459.

ECE (Economic Commission for Europe). (2001), Terminology on combined transport, prepared by the UN/ECE, the European Conference of Ministers of Transport (ECMT) and the European Commission (EC), United Nations, New York and Geneva.

ECMT (European Conference of Ministers of Transport). (2006a), Inland Waterways and Environmental Protection, OECD, Paris.

ECMT (European Conference of Ministers of Transport). (2006b), Strengthening Inland Waterway Transport. Pan-European Co-operation for Progress. OECD: Paris

FRANC, P. (2007), Intérêts et rentabilités des dessertes terrestres massifiées pour les armements de lignes régulières conteneurisées, Les cahiers scientifiques du transport, N52/2007, pp. 119-142.

FRANC, P., FREMONT, A. (2009), Le transport fluvial de conteneurs : l'enjeu énergétique, Transports, Forthcoming.

FREMONT, A., FRANC, P., SLACK, B. (2009), Inland barge services and container transport: the case of the ports of Le Havre and Marseille in the European context, Cybergéo, 437. http://www.cybergeo.eu/index21743.html

GOUVERNAL, E., DAYDOU, J. (2005), Container railfreight services in North-west Europe : diversity of organizational forms in a liberalizing environment. Transport reviews, Vol. 25, No. 5, pp 557-571.

HAYUTH, Y. (1981), Containerization and the Load Center Concept, Economic Geography, 57 (2), 160-176.

HEAVER, T. (2002), The evolving roles of shipping lines in international logistics, International Journal of Maritime Economics, 4, pp. 210-230.

KONINGS, R. (2006), Hub-and-spoke networks in container-on-barge transport, paper presented at the TRB meeting, 2006.

NIERAT, P. (1997), Market area of rail-truck terminals: pertinence of the spatial theory, Transportation Research, 31A (2), pp.109-127. 
NOTTEBOOM, T. (2004), A carrier's perspective on container network configuration at sea and on land, Journal of International Logistics and Trade, 1 (2), 65-87.

NOTTEBOOM, T., KONINGS, R. (2004), Network dynamics in container transport by barge, Belgéo, 4, 461-478.

NOTTEBOOM, T., WINKELMANS, W. (2001), Structural changes in logistics: how will port authorities face the challenge? Maritime Policy and Management, Vol. 28, No. 1, pp 7189.

PANAYIDES, P.M., CULLINANE, K. (2002), Competitive advantage in liner shipping: a review and research agenda, International Journal of Maritime Economics, 4, 189-209.

RODRIGUE, J.P., NOTTEBOOM, T. (2009a), The terminalization of supply chains: reassessing the role of terminals in port/hinterland relationships, Maritime Policy and Management, Vol. 36, No. 2, pp. 165-183.

RODRIGUE, J.P., NOTTEBOOM, T. (2009b), The geography of containerization: half a century of revolution, adaptation and diffusion, Geojournal, 74, pp. 1-5.

ROBINSON, R. (2002), Ports as elements in value-driven chain systems: the new paradigm, Maritime Policy and Management, Vol. 29, No. 3, pp 241-255.

SLACK, B. (1999), Satellite terminals: a local solution to hub congestion? Journal of Transport Geography, 7, 241-246.

VAN DER HORST, M.R., DE LANGEN, P.W. (2008), Coordination in hinterland transport chains: a major challenge for the seaport community, Journal of Maritime Economics \& Logistics, Vol. 10, pp. 108-129.

WIEGMANS, B., KONINGS, R. (2007), Strategies and innovations to improve the performance of barge transport, EJTIR, 7, 2, pp. 145-162.

ZURBACH, V. (2005), Transport de conteneurs sur le Rhin: Quelles logiques de fonctionnement ? Rapport de Master Recherche "Transports », Université de Paris 12, année 2004-2005, 76 p. 